\title{
In Vitro Antimicrobial Activity of Calcium Hydroxide Pastes and their Vehicles Against Selected Microorganisms
}

\author{
Brenda Paula Figueiredo de Almeida GOMES ${ }^{1}$ \\ Caio Cezar Randi FERRAZ ${ }^{1}$ \\ Morgana Eli VIANNA ${ }^{1}$ \\ Pedro Luiz ROSALEN ${ }^{2}$ \\ Alexandre Augusto ZAIA ${ }^{1}$ \\ Fabricio Batista TEIXEIRA $^{1}$ \\ Francisco José de SOUZA-FILHO ${ }^{1}$ \\ Departments of ${ }^{1}$ Restorative Dentistry, Endodontic Area, and ${ }^{2}$ Pharmacology, Dental School of Piracicaba, UNICAMP, \\ Piracicaba, SP, Brazil

\begin{abstract}
The aim of this study was to investigate in vitro the antimicrobial activity of calcium hydroxide in combination with several vehicles against some microorganisms commonly isolated from root canals. Antimicrobial activity was determined by the agar diffusion method. Stainless-steel cylinders were placed on each inoculated agar medium. The test medicaments and their controls were placed inside the cylinders. The zones of growth inhibition were measured and recorded after incubation for each plate and the results were analyzed statistically (ANOVA). The in vitro antimicrobial effects of the medications were ranked from strongest to weakest as follows: $\mathrm{Ca}(\mathrm{OH})_{2}+\mathrm{CMCP}+$ glycerine, $\mathrm{Ca}(\mathrm{OH})_{2}+\mathrm{CMCP}, \mathrm{Ca}(\mathrm{OH})_{2}+$ glycerine, $\mathrm{Ca}(\mathrm{OH})_{2}+$ anesthetic, $\mathrm{Ca}(\mathrm{OH})_{2}+\mathrm{saline}, \mathrm{Ca}(\mathrm{OH})_{2}+\mathrm{H} \mathrm{H}_{2} \mathrm{O}$, $\mathrm{Ca}(\mathrm{OH})_{2}+$ polyethyleneglycol. The pastes with oily vehicles showed significantly larger mean zones of inhibition compared to those with aqueous or viscous vehicles. It was concluded that diffusion and antimicrobial activity of calcium hydroxide were affected by the type of vehicle used.
\end{abstract}

Key Words: intracanal medication, calcium hydroxide, microorganisms.

\section{INTRODUCTION}

The role of bacteria and their by-products in the initiation and perpetuation of pulp and periapical diseases has been well established. Most infecting bacteria, together with their principal substrate of necrotic pulp debris, may be removed by routine endodontic procedures such as instrumentation and irrigation, and the use of an intracanal medicament with antimicrobial activity. Nevertheless, this is not always fully achieved in clinical practice. The anatomical complexities of many root canals, and consequent limitations of access by instruments, irrigants and intracanal medications are well known (1). Despite the antimicrobial properties of the chemomechanical preparation and the intracanal dressings, the elimination of the microorganisms may not be uniform due to the vulnerability of the involved species (2).

Even though anaerobic bacteria, especially blackpigmented Gram-negative, have been linked to signs and symptoms $(3,4)$, facultative bacteria, such as $E n$ terococcus faecalis, have been considered one of the most resistant species in the oral cavity and a possible cause of failure of root canal treatment $(2,5)$.

It has long been recognized that the antibacterial effects of biomechanical procedures can be enhanced by the subsequent placement of an antimicrobial intracanal medication such as calcium hydroxide $\left(\mathrm{Ca}(\mathrm{OH})_{2}\right)(6)$. Calcium hydroxide was first introduced as a pulp capping agent in 1930 by Hermann and since then its use in endodontic therapy has increased. Today it is one of the most versatile medications in dentistry, 
especially for its use as an intracanal dressing. Moreover, calcium hydroxide is considered to fulfill many of the properties of an ideal root canal dressing due to its moderate antibacterial action, its ability to induce hard tissue formation and to cause intracanal occlusion, and its tissue dissolving capability (7).

For calcium hydroxide to act effectively as an intracanal dressing, it should ideally occupy all of the pulp space, thereby diffusing into areas inaccessible to instruments. Its effectiveness is linked to the diffusion of hydroxyl ions through the dentinal tubules and accessory canals into areas where bacteria and their byproducts may be harbored. In addition to acting as a physical barrier, the calcium hydroxide dressing may both prevent root canal re-infection and interrupt the nutrient supply to the remaining bacteria. Its alkalizing $\mathrm{pH}$ (around 12.5) promotes a destructive effect on cell membranes and protein structure (8).

Recent studies have reviewed the classification and clinical indications of various formulations of calcium hydroxide $(9,10)$ and their mechanisms of antimicrobial activity (11), clearly indicating that even though this medication has been used for more than 80 years, there are still many questions to be answered regarding its antimicrobial action.

The agar diffusion method has been widely used to test antimicrobial activities of endodontic medicaments and sealers $(12,13)$. It allows direct comparison of intracanal medicaments against the test microorganisms, indicating which medication has the potential to eliminate bacteria from the root canal system.

The purpose of this study was to assess in vitro the antimicrobial activity of calcium hydroxide associated with several vehicles against aerobes and facultative and strictly anaerobic microorganisms commonly isolated from root canals. The antimicrobial activity of the vehicles was also evaluated.

\section{MATERIAL AND METHODS}

The microorganisms used in this experiment were two aerobes, six facultative anaerobic bacteria, and four black-pigmented Gram-negative anaerobes commonly isolated from infected root canals: Candida albicans NTCC 3736, Bacillus subtilis ATCC 19659, Staphylococcus aureus ATCC 25923, Enterococcus faecalis ATCC 29212, Streptococcus sanguis ATCC 10556, Streptococcus sobrinus 6715, Streptococcus mutans OMZ 175, Actinomyces naeslundii M104, Porphyromonas gingivalis, Porphyromonas endodontalis, Prevotella intermedia/nigrescens and Prevotella denticola. The last four microorganisms were isolated from clinical trials. The aerobes and facultative anaerobes were kindly donated by the Center of Oral Biology, University of Rochester, NY, USA.

Each microbial strain was evaluated against calcium hydroxide pastes prepared with the following vehicles: a) sterile distilled water (aqueous vehicle); b) sterile saline (aqueous vehicle); c) anesthetic solution (aqueous vehicle, 3\% carbocaine (mepivacaine) with no vasoconstrictor; Sterling Drug, New York, NY); d) glycerine (viscous vehicle); d) polyethyleneglycol (viscous vehicle, proprietary brand: Calen ${ }^{\mathrm{TM}}$; S.S. White Artigos Dentários, Rio de Janeiro, RJ, Brazil); e) camphorated paramonochlorophenol (CMCP, oily vehicle; Frank's paste, $2: 1)$; f) CMCP + glycerine (2:1:1). Distilled water, $0.85 \%$ sterile saline, anesthetic solution, glycerine, polyethyleneglycol, CMCP and CMCP + glycerine (1:1) were used as controls.

The calcium hydroxide pastes were prepared using calcium hydroxide powder (Mallinckrodt, Inc., Phillipsburg, NJ, USA). The consistency of the pastes was similar to that of toothpaste, with a viscosity of $3501 \mathrm{cP}$ at $0.1 \mathrm{rpm}$ (Brookfield Digital Reometer, model DV-III-IV, São Paulo, SP, Brazil), and pH 12.5 determined with a $\mathrm{pH}$ meter (Analion, $\mathrm{pH}$ digital PM 605, Ribeirão Preto, SP, Brazil). Calen is the proprietary brand of Leonardo and Leal's paste, with the following formulation: calcium hydroxide $(2.5 \mathrm{~g})$, zinc oxide $(0.5 \mathrm{~g})$, hydrogenized colophony $(0.05 \mathrm{~g})$ and polyethyleneglycol $400(12.75 \mathrm{ml})$. This is the only proprietary brand of a calcium hydroxide paste containing this viscous vehicle (10).

All microorganisms were previously subcultured in appropriate culture media and under gaseous conditions to confirm their purity.

Aerobe and facultative strains were individually inoculated into tubes containing $5 \mathrm{ml}$ of sterile $0.85 \%$ saline solution. The suspension was adjusted spectrophotometrically to match the turbidity of a McFarland 0.5 scale. Five hundred $\mu l$ of each test microorganism suspension was inoculated into glass bottles containing $50 \mathrm{ml}$ of $\mathrm{BHI}$ agar at $46^{\circ} \mathrm{C}$, vortexed, and poured onto $130-\mathrm{mm}$ plates containing a previously set layer of Mueller Hinton (MH) agar (Oxoid, Unipath Ltd, Basingstoke, UK). 
For the anaerobes, isolated colonies were suspended to reach 1.0 on the McFarland scale. Sterile swabs were dipped into the bacterial suspension and inoculated onto pre-reduced 70 -mm plates containing 5\% sheep-blood-Fastidious Anaerobe Agar (FAA; Lab$\mathrm{M}$, Bury, UK). The inoculum procedures used were appropriate to provide a semi-confluent growth of the tested microorganisms.

Sterile stainless-steel tubes of $8.0 \times 1.0 \times 10 \mathrm{~mm}$ (inner diameter, $6 \mathrm{~mm}$ ) were added to the surfaces of the media and filled with $40 \mu \mathrm{l}$ of each test substance and its control. The plates were kept for $2 \mathrm{~h}$ at room temperature to allow the diffusion of the agents through the agar and then incubated at $37^{\circ} \mathrm{C}$ under appropriate gaseous conditions and for an appropriate period of time: aerobes, $24 \mathrm{~h}$; facultatives, $24-48 \mathrm{~h}$ in a $\mathrm{CO}_{2}$ incubator (Jouan, Saint Herblain, France), in an atmo- sphere of $10 \% \mathrm{CO}_{2}$; anaerobes in an anaerobic work station (Don Whitley Scientific, Bradford, UK) in an atmosphere of $5-10 \% \mathrm{H}_{2}, 10 \% \mathrm{CO}_{2}, 80-85 \% \mathrm{~N}_{2}$ for 7 days. Zones of inhibition of microbial growth around the cylinder containing the tested substances were measured and recorded after the incubation period. The inhibitory zone was considered to be the shortest distance $(\mathrm{mm})$ from the outer margin of the cylinder to the initial point of the microbial growth. Six replicates were made for each microorganism. Analysis of variance (ANOVA) was used to determine the differences in susceptibility to intracanal medication between microbial species.

\section{RESULTS}

Table 1 shows the mean area of the zones of

Table 1. Mean area of the zones of microbial growth inhibition (in $\mathrm{mm}$ ) provided by calcium hydroxide associated with several vehicles.

\begin{tabular}{|c|c|c|c|c|c|c|c|c|c|c|c|c|}
\hline $\mathrm{Ca}(\mathrm{OH})_{2}+$ & C.a. & B.s. & S.a. & E.f. & S.sa. & S.s. & S.m. & A.n. & $P . g$. & P.e. & P.i./P.n. & P.d. \\
\hline sterile water & 2.3 & 0.5 & 0 & 0 & 0 & 0 & 0 & 0 & 0 & 0 & 0 & 0 \\
\hline saline & 2.6 & 1.0 & 0 & 0 & 0 & 0 & 0 & 0 & 0 & 0 & 0 & 0 \\
\hline anesthetic solution & 2.6 & 1.0 & 0 & 0 & 0 & 0 & 0 & 0 & 0 & 0 & 0 & 0 \\
\hline glycerine & 2.8 & 1.0 & 0 & 0 & 0 & 0 & 0 & 0 & 0 & 0 & 0 & 0 \\
\hline polyethyleneglycol & 1.7 & 0.7 & 0 & 0 & 0 & 0 & 0 & 0 & 0 & 0 & 0 & 0 \\
\hline CMCP & 3.5 & 3.8 & 4.7 & 0.7 & 2.5 & 1.5 & 1.5 & 2.5 & 5.5 & 6.2 & 5.0 & 5.0 \\
\hline CMCP + glycerine & 11.3 & 6.5 & 11.7 & 7.2 & 12.0 & 10.2 & 11.3 & 8.7 & 22.0 & 25.0 & 19.0 & 15.6 \\
\hline
\end{tabular}

C.a.: C. albicans; B.s.: B. subtilis; S.a.: S. aureus; E.f.: E. faecalis; S.sa.: S. sanguis; S.s.: S. sobrinus; S.m.: S. mutans; A.n.: A. naeslundii; P.g.: P. gingivalis; P.e.: P. endodontalis; P.i./P.n.: P. intermedia/nigrescens; P.d.: P. denticola. CMCP: camphorated paramonochlorophenol. Zero means inhibition by direct contact.

Table 2. Mean area of the zones of microbial growth inhibition (in mm) provided by the vehicles.

\begin{tabular}{|c|c|c|c|c|c|c|c|c|c|c|c|c|c|}
\hline Vehicles & C.a. & B.s. & S.a. & E.f. & S.sa. & S.s. & S.m. & A.n. & P.g. & P.e. & P.i./P.n. & P.d. & $\begin{array}{c}\text { Average values of each } \\
\text { vehicle against all } \\
\text { microorganisms tested }\end{array}$ \\
\hline sterile water & $*$ & $*$ & * & $*$ & $*$ & * & $*$ & $*$ & * & $*$ & $*$ & * & $*$ \\
\hline saline & $*$ & $*$ & $*$ & $*$ & $*$ & $*$ & $*$ & $*$ & $*$ & $*$ & $*$ & $*$ & $*$ \\
\hline anesthetic solution & $*$ & $*$ & $*$ & $*$ & $*$ & $*$ & $*$ & $*$ & $*$ & $*$ & $*$ & $*$ & $*$ \\
\hline glycerine & $*$ & $*$ & $*$ & $*$ & $*$ & $*$ & $*$ & $*$ & $*$ & $*$ & $*$ & $*$ & $*$ \\
\hline polyethyleneglycol & $*$ & $*$ & $*$ & $*$ & $*$ & $*$ & $*$ & $*$ & $*$ & $*$ & $*$ & $*$ & $*$ \\
\hline CMCP & 4.0 & 3.0 & 5.3 & 3.0 & 6.0 & 6.0 & 2.5 & 5.0 & 11.0 & 12.5 & 10.0 & 6.0 & 6.19 \\
\hline $\mathrm{CMCP}+$ glycerine & 4.5 & 3.5 & 7.0 & 5.0 & 13.5 & 13.5 & 5.0 & 5.0 & 13.0 & 15.0 & 12.0 & 8.0 & 8.75 \\
\hline
\end{tabular}

C.a.: C. albicans; B.s.: B. subtilis; S.a.: S. aureus; E.f.: E. faecalis; S.sa.: S. sanguis; S.s.: S. sobrinus; S.m.: S. mutans; A.n.: A. naeslundii; P.g.: P. gingivalis; P.e.: P. endodontalis; P.i./P.n.: P. intermedia/nigrescens; P.d.: P. denticola.

CMCP: camphorated paramonochlorophenol. *Microbial growth 


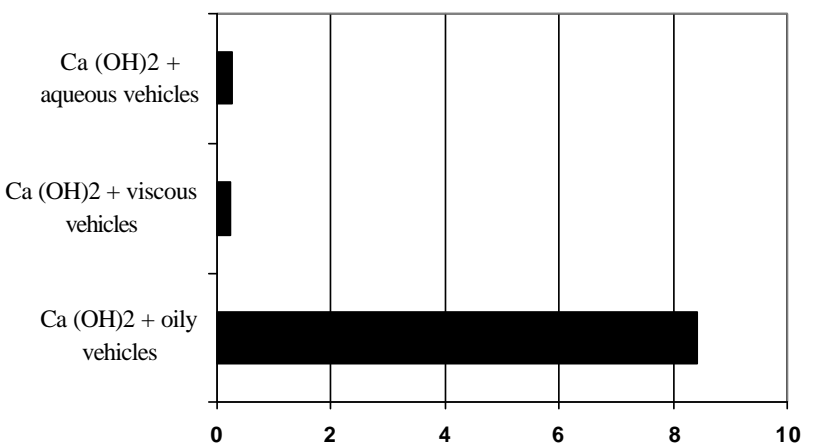

Figure 1. Average values of growth inhibition zones (in $\mathrm{mm}$ ) by $\mathrm{Ca}(\mathrm{OH})_{2}$ paste in combination with several vehicles against all microorganisms tested.

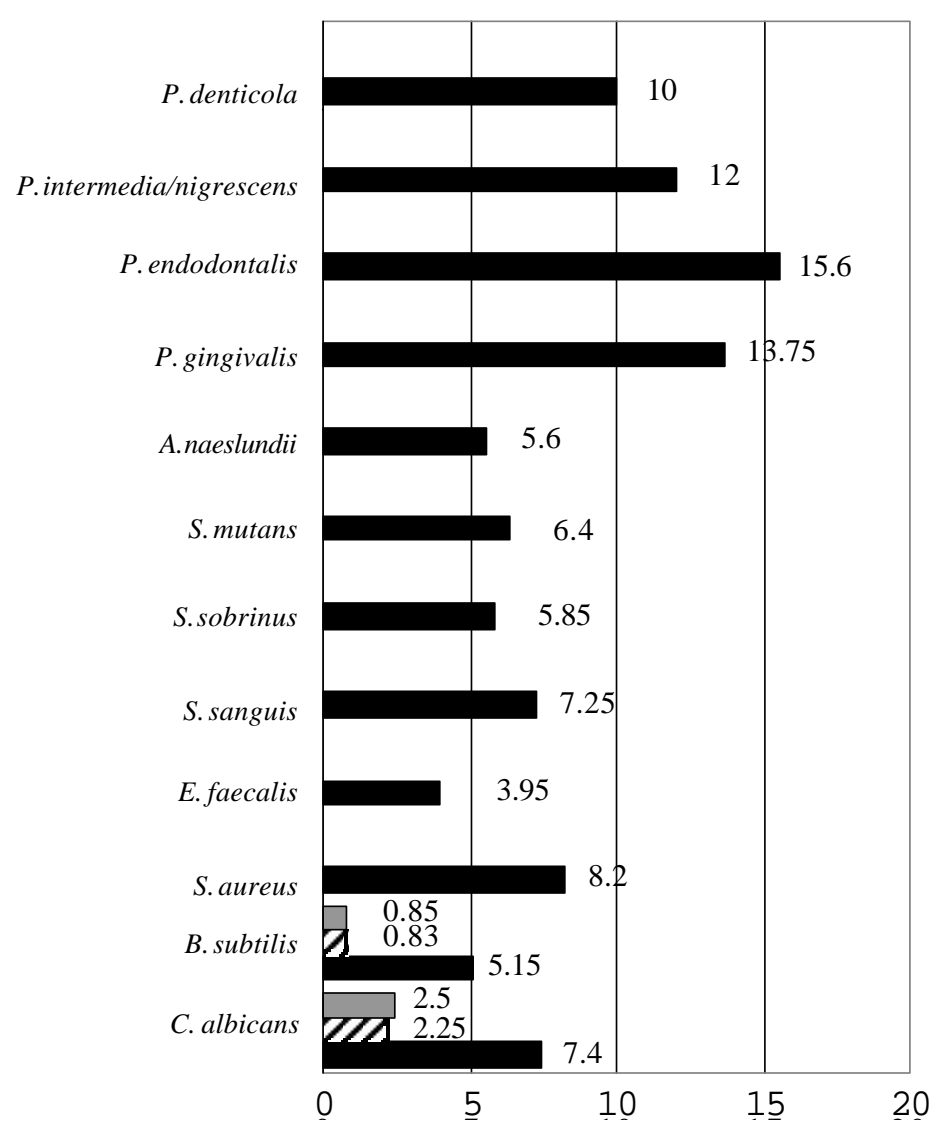

$$
\begin{aligned}
& \square \mathrm{Ca}(\mathrm{OH})_{2}+\text { aqueous vehicles } \\
& \square \mathrm{Ca}(\mathrm{OH})_{2}+\text { viscous vehicles } \\
& \square \mathrm{Ca}(\mathrm{OH})_{2}+\text { oily vehicles }
\end{aligned}
$$

Figure 2. Average values of growth inhibition zones (in $\mathrm{mm}$ ) by $\mathrm{Ca}(\mathrm{OH})_{2}$ paste in combination with several vehicles against all microorganisms tested. microbial inhibition (in $\mathrm{mm}$ ) provided by calcium hydroxide associated with several vehicles. Zones of microbial inhibition equal to zero mean that the medication had antimicrobial action by direct contact, however, without halo formation. All calcium hydroxide pastes were inhibitory at least by direct contact against all microbial strains tested (Table 1).

Based on the averages of the diameters of the zones of microbial growth inhibition, the antimicrobial effects of the $\mathrm{Ca}(\mathrm{OH})_{2}$ pastes could be ranked from strongest to weakest according to the vehicle group, as follows: $\mathrm{Ca}(\mathrm{OH})_{2}+\mathrm{CMCP}$ + glycerine, $\mathrm{Ca}(\mathrm{OH})_{2}+\mathrm{CMCP}, \mathrm{Ca}(\mathrm{OH})_{2}+$ glycerine, $\mathrm{Ca}(\mathrm{OH})_{2}+$ anesthetic, $\mathrm{Ca}(\mathrm{OH})_{2}+$ saline, $\mathrm{Ca}(\mathrm{OH})_{2}+\mathrm{H}_{2} \mathrm{O}, \mathrm{Ca}(\mathrm{OH})_{2}+$ polyethyleneglycol. The pastes with oily vehicles showed significantly larger mean zones of inhibition $(8.42 \mathrm{~mm})$ compared with those with aqueous $(0.25 \mathrm{~mm})$ or viscous vehicles $(0.27 \mathrm{~mm})(\mathrm{p}<0.05)$ (Figure 1$)$.

The aqueous and viscous vehicles such as water, saline, anesthetic, glycerine and polyethyleneglycol had no antimicrobial action. On the other hand, the oily vehicles such as CMCP and CMCP plus glycerine showed average inhibition zones of microbial growth of $6.19 \mathrm{~mm}$ and 8.75 $\mathrm{mm}$, respectively (Table 2 ).

The susceptibility of individual microorganisms to the calcium hydroxide pastes was varied. All microorganisms were more susceptible to calcium hydroxide prepared with oily vehicles. E. faecalis was most resistant (3.95 $\mathrm{mm})$, followed by B. subtilis $(55.15 \mathrm{~mm})$ and $A$. naeslundii M104 (5.6 mm), while the anaerobic $P$. endodontalis $(15.6 \mathrm{~mm})$, followed by Porphyomonas gingivalis $(13.75 \mathrm{~mm})$ and Prevotella intermedia/nigrescens $(12 \mathrm{~mm})$, were more susceptible to pastes with oily vehicles. However, B. subtilis and C. albicans showed some susceptibility to all calcium hydroxide pastes (Figure 2).

\section{DISCUSSION}

Common clinical signs such as exudation, hemorrhage, perforation, root resorption, trauma or incomplete root formation may indicate the need for intracanal medicaments. In 
these situations, it is beneficial to clean and shape the canals and place the $\mathrm{Ca}(\mathrm{OH})_{2}$ paste densely into the full length of the canal, in order to increase the efficacy of the antimicrobial effect (8).

The calcium hydroxide antimicrobial action is related to the alkaline $\mathrm{pH}$. The change of dentinal $\mathrm{pH}$ caused by hydroxyl ions is slow and depends on several factors that can alter the rate of ionic dissociation and diffusion, such as the level of hydrosolubility of the vehicle employed, difference in viscosity, acid-base characteristics, dentinal permeability, and level of existing calcification (14). The lethal effects of hydroxyl ions on bacterial cells are probably due to the damage to the bacterial cytoplasmic membrane, protein denaturation, and damage to the DNA (11). The time needed for calcium hydroxide to optimally disinfect the root canal is still unknown and might be related to the type of microorganism involved, location of the microorganism in the root canal system, presence or absence of smear layer and presence or absence of root canal exudation.

Moreover, $\mathrm{Ca}(\mathrm{OH})_{2}$ should ideally be placed so that it occupies the apical regions in sufficient quantity to permit its biological effect to be exerted in close proximity to the appropriate tissues. In many clinical situations, the correct placement of $\mathrm{Ca}(\mathrm{OH})_{2}$ paste into the root canal system may be hindered due to anatomical irregularities. In most cases, $\mathrm{Ca}(\mathrm{OH})_{2}$ should be combined with a liquid acting as a carrier because some researchers have found that techniques that deliver dry calcium hydroxide powder alone are difficult or impossible to use in smaller, curved canals (15). In general dental practice, sterile water or saline are among the most commonly used carriers and are also effective in delivering hydroxyl ions (8).

According to Fava and Saunders (10), the vehicle plays a most important role in the biological action of calcium hydroxide which is determined by the velocity of ionic dissociation in $\mathrm{Ca}^{++}$and $\mathrm{OH}^{-}$ions. The aqueous vehicles are represented in this study by sterile water, sterile saline and anesthetic solution, although this category also includes Ringer's solution, methylcellulose and carboxymethylcellulose, and anionic detergent solutions such as sodium lauryl diethyleneglycol or sodium lauryl sulfate. Generally, aqueous solutions promote a rapid ion liberation and should be used in clinical situations involving intense exudate, and dental replantation, among others, being the best vehicle for
$\mathrm{Ca}(\mathrm{OH})_{2}$ powder (8). Although acidic, with a $\mathrm{pH}$ ranging from 4 to 5 , local anesthetics provide an adequate mixing agent because calcium hydroxide is a very strong base minimally affected by the acid (16).

Viscous vehicles (glycerine, polyethyleneglycol, propyleneglycol) are also water-soluble substances that release $\mathrm{Ca}^{++}$and $\mathrm{OH}^{-}$ions more slowly for extended periods. These should be used for redressing, because the paste may remain in the root canal for a longer period. Several investigators have claimed that calcium hydroxide pastes containing viscous vehicles such as glycerine incorporate more $\mathrm{Ca}(\mathrm{OH})_{2}$ than aqueous vehicles in order to achieve a toothpaste consistency, and their delivery into canals with a Lentulo spiral is a superior method of placement for length and density (15). Pastes containing oily vehicles (olive oil, camphorated paramonochlorophenol, metacresylacetate, eugenol) have restricted application, and their use has been reported in clinical situations that require a very slow ion dissociation, i.e., a permanent root filling for perforation defects after internal resorption (10).

In the present study, all calcium hydroxide pastes mixed with inert vehicles had antimicrobial action, but just by direct contact, in agreement with previous studies (17). Other studies have also reported the failure of calcium hydroxide to eliminate enterococci effectively $(2,6)$ as they tolerate very high $\mathrm{pH}$ values, varying from 9 to 11 . In the present study, Enterococcus faecalis was the microorganism showing the smallest inhibition zone against all tested intracanal medications, while strict anaerobes such as Porphyromonas endodontalis, $P$. gingivalis and Prevotella intermedia/nigrescens showed the largest inhibition zones.

Pastes prepared with aqueous vehicles had a lower antimicrobial action in the following crescent order: water, saline and anesthetic. Glycerine (a viscous vehicle) mixed with $\mathrm{Ca}(\mathrm{OH})_{2}$ produced larger zones of microbial growth inhibition compared to the aqueous vehicles. On the other hand, polyethyleneglycol (also a viscous vehicle) showed the weakest antimicrobial action, confirming a previous study (18). The in vitro ineffectiveness of calcium hydroxide mixed with inert vehicles may be related to the fact that culture media possess buffer substances in their formulations and also due to the vehicle diffusion ability. Therefore, although calcium hydroxide could have diffused across the medium, the $\mathrm{pH}$ levels reached were not sufficient to present inhibitory activity (11). 
Some in vivo studies have indicated that killing of microbes in the canal can be achieved more reliably with calcium hydroxide paste mixed with aqueous vehicle than with other medicaments tested (6). This may be explained by the filling ability of these pastes, which may be more relevant in preventing recontamination than the chemical effect. Because calcium hydroxide has a low water solubility, it is slowly dissolved in saliva, thus remaining in the canal for a long period of time, delaying bacterial progression toward the apical foramen. The present study has shown that $\mathrm{Ca}(\mathrm{OH})_{2}$ pastes kill bacteria by direct contact, which means that the remaining microorganisms in contact with this medication in the root canal will be eradicated if they are not tolerant to this medication.

As verified in the present study, the superior in vitro antimicrobial activity of calcium hydroxide associated with camphorated paramonochlorophenol (CMCP) has long been recognized. The addition of glycerine to Frank's paste seems to enhance its antimicrobial action since glycerine helps the diffusibility of $\mathrm{Ca}(\mathrm{OH})_{2}+\mathrm{CMCP}(17)$, as also observed in the present study.

In conclusion, even though calcium hydroxide is the recommended intracanal medication for the treatment of apical periodontitis, it cannot be considered as a universal intracanal medicament, since it is not equally effective against all bacteria found in the root canal. The association of calcium hydroxide to $\mathrm{CMCP}$ aiming to improve its antimicrobial property should be avoided, as this vehicle can be irritating to periapical tissues (8). Another medication or association, such as $2 \%$ chlorhexidine gel should be considered, which is biocompatible with periapical tissues, has a wide spectrum of antimicrobial activity with prolonged action and diffuses through the dentine tubules $(12,19)$.

The first step in a study of the effectiveness of intracanal medicament is the laboratory test. In vitro research to determine the antimicrobial activity depends on the sensitivity of the drug, bacterial source (wild strains or collection species), number of bacteria inoculated, $\mathrm{pH}$ of the substrates in plates or tubes, agar viscosity, storage conditions of the agar plates, incubation time and the metabolic activity of the microorganisms. On the other hand, the duration of effectiveness of the drug, temperature, contamination and possible leakage of the agent into the mouth must be considered while working in vivo (20).
The present study confirmed some published data on the in vitro antimicrobial activity of calcium hydroxide associated with several vehicles, and also provided new data on the susceptibility of endodontic related microorganisms to the intracanal medicaments tested.

Thus, we conclude that the type of vehicle utilized affects the diffusion ability and the antimicrobial activity of calcium hydroxide. However, in vitro results must be analyzed carefully before their extrapolation to clinical conditions. Research is in progress to evaluate the antibacterial effectiveness of these pastes as intracanal medications using other in vitro tests and also in vivo models.

\section{ACKNOWLEDGEMENTS}

We would like to thank Dr. M. Campbell from the University of Manchester, UK, for the invaluable statistical help. This work was supported by the Brazilian agencies FAPESP (grant no. 2000/13689-7 \& 1996/ 5584-3), CNPq (520277/99-6) and CAPES.

\section{RESUMO}

Gomes BPFA, Ferraz CCR, Vianna ME, Rosalen PL, Zaia AA, Teixeira FB, de Souza-Filho FJ. Atividade antimicrobiana in vitro das pastas de hidróxido de cálcio e seus veículos sobre microrganismos específicos. Braz Dent J 2002;13(3):155-161.

O objetivo deste trabalho foi investigar in vitro a atividade antimicrobiana do hidróxido de cálcio em combinação com vários veículos contra alguns microrganismos mais

frequentemente isolados dos canais radiculares. A atividade antimicrobiana foi determinada pelo método de difusão no ágar. Cilindros de aço inoxidável foram colocados sobre as placas de agar já inoculadas, dentro dos quais os medicamentos testados e seus controles foram introduzidos. As zonas de inibição do crescimento microbiano foram medidas e anotadas após o período de incubação de cada placa e os resultados foram analisados estatisticamente. A atividade antimicrobiana in vitro dos medicamentos testados, em ordem decrescente, foi: $\mathrm{Ca}(\mathrm{OH})_{2}+$ $\mathrm{PMCF}+$ glicerina, $\mathrm{Ca}(\mathrm{OH})_{2}+\mathrm{PMCF}, \mathrm{Ca}(\mathrm{OH})_{2}+$ glicerina, $\mathrm{Ca}(\mathrm{OH})_{2}+$ anestésico, $\mathrm{Ca}(\mathrm{OH})_{2}+$ salina, $\mathrm{Ca}(\mathrm{OH})_{2}+\mathrm{H}_{2} \mathrm{O}$, $\mathrm{Ca}(\mathrm{OH})_{2}+$ polietilenoglicol. Pastas com veículos oleosos produziram as maiores zonas de inibição, quando comparadas com as com veículos aquosos ou oleosos. Concluimos que a habilidade de difusão e a atividade antimicrobiana do hidróxido de cálcio estão relacionadas com os tipos de veículos utilizados.

Unitermos: medicação intracanal, hidróxido de cálcio, microrganismos. 


\section{REFERENCES}

1. Biffi JC, Rodrigues HH. Ultrasound in endodontics. a quantitative and histological assessment using human teeth. Endod Dental Traumatol 1989;5:55-62.

2. Gomes BPFA, Lilley JD, Drucker DB. Variations in the susceptibilities of components of the endodontic microflora to biome chanical procedures. Int Endod J 1996;29:235-241.

3. Gomes BPFA, Drucker DB, Lilley JD. Association of specific bacteria with some endodontic signs and symptoms. Int Endod $\mathrm{J}$ 1994;27:291-298.

4. Gomes BPFA, Lilley JD, Drucker DB. Clinical significance of dental root canal microflora. J Dent 1996; 29:47-55.

5. Molander A, Reit C, Dahlén G, Kvist T. Microbiological status of root-filled teeth with periodontitis. Int Endod J 1998;31:1-7.

6. Byström A, Claesson R, Sundqvist G. The antibacterial effect of camphorated paramonochlorophenol, camphorated phenol and calcium hydroxide in the treatment of infected root canals. Endod Dental Traumatol 1985;1:170-175.

7. Nerwich A, Figdor D, Messer HH. pH changes in root dentin over a 4-week period following root canal dressing with calcium hydroxide. J Endodon 1993;19:302-306.

8. Spangberg LSW. Intracanal medication. In: Endodontics. Ingle JI, Bakland L. eds. 4th ed. Baltimore: Williams \& Wilkins, 1994. p 627-640.

9. Estrela C, Pécora JD, Souza-Neto MD, Estrela CR, Baummann LL. Effect of vehicle on antimicrobial properties of calcium hydroxide. Braz Dent J 1999;10:63-72.

10. Fava LRG, Saunders WP. Calcium hydroxide pastes: classification and clinical indications. Int Endod J 1999;32:267-282.
11. Siqueira Jr JF, Lopes HP. Mechanisms of antimicrobial activity of calcium hydroxide: a critical review. Int Endod J 1999;32:361369.

12. Siqueira Jr JF, Uzeda M. Intracanal medicaments: evaluation of the antibacterial effects of chlorhexidine, metronidazole, and calcium hydroxide associated with three vehicles. J Endodon 1997;23:167-169.

13. Mickel AK, Wright R. Growth inhibition of Streptococcus anginosus (milleri) by three calcium hydroxide sealers and one zinc oxide-eugenol sealer. J Endodon 1999;25:34-37.

14. Estrela C, Pimenta FC, Ito II, Baummann LL. In vitro determination of direct antimicrobial effect of calcium hydroxide. J Endodon 1998;24:15-17.

15. Rivera EM, Williams K. Placement of calcium hydroxide in simulated canals: comparison of glycerin versus water. J Endodon 1994;20:445-448.

16. Statmos DG, Haasch GG, Gerstein $\mathrm{H}$. The $\mathrm{pH}$ of local anesthetic/ calcium hydroxide solutions. J Endodon 1985;11:264-265.

17. Siqueira Jr JF, Uzeda M. Influence of different vehicles on the antibacterial effects of calcium hydroxide. J Endodon 1998;6:6365

18. Gomes BPFA, Ferraz CCR, Souza-Filho FJ, Rosalen PL, Lilley JD. Susceptibility of selected microorganisms to intracanal medicaments. Int Endod J 2000;33:72 9 (abstract).

19. Ferraz CCR, Gomes BPFA, Zaia AA, Teixeira FB, Souza-Filho FJ. In vitro assessment of chlorhexidine gel as an endodontic irrigant. J Endodon (in press).

20. Weiss EI, Shalhav M, Fuzz Z. Assessment of antibacterial activity of endodontic sealers by a direct contact. Endod Dent Traumatol 1986;12:179-184. 